\title{
REPARATION A MORALE JUSTICE FOR AFRICA: THE BENIN (NIGERIA) IN PERSPECTIVE
}

\author{
S. O. Idahosa \\ Peoples' Friendship University of Russia (RUDN University), Moscow, Russia
}

\section{J. A. Onimhawo, S. I. Ikhidero}

Ambrose Alli University, Ekpoma, Nigeria

\begin{abstract}
The paper offered a review of Africa's moral call for reparation. It emphasized among other things that the continued underdevelopment and marginalization of the African continent today, is not unconnected with the trilogy of slavery, imperialism and colonialism. From the perspective of the British expedition of the Great Benin Kingdom in 1897, the paper highlighted how the African continent had been brutalized to strengthen the economies of their colonial overlords. The paper anchored its call for reparation on the premise that, reparation is not only recognized in international law, it has been paid to countries of the world whose dehumanizing experiences are not even as pathetic as those of Africa's over 500 years of abject treatment, damages and destruction occasioned by slavery, imperialism and colonialism. It unveiled also the scholarly argument opposed to reparation.

The work thus proposes that reparations from the western countries to Africa should be on cooperative and partnership basis. This should be in favour of development through deliberate international efforts in recompensing Africa for all the ills visited on her by the west.
\end{abstract}

Key words: reparations, Imperialism, Colonialism, Justice, Western Powers, Benin Kingdom

In recent years, there has been a surge in the call for the reparation of the African continent. This basically is to compensate for the horrifying atrocities committed against Africans especially by the Europeans in the name of Slavery, colonialism and even neocolonialism. Africans, having realized that the legacies of these past atrocities contribute in a great measure to keeping the continent at the bottom of the global hierarchy are demanding earnestly for restitution.

As historical evidence reveals that the African continent once the cradle and home of human civilization developed at a fast pace favourably comparable to the fastest growing regions of the world ${ }^{1}$. Oliver and Fage ${ }^{2}$ noted that, "while the centers of European culture flourished, decayed and sprouted in their turn, empires in Africa rose, ruled, resisted and succumbed; scholars studied and disputed in Timbuktu as in Paris, and what Italians accomplished with pigment, the artists of Benin achieved with bronze".

Series of agonizing developmental distortion (not unconnected with slave-trade and colonialism) however, became the clog on the wheel of Africa's steady march to

1 Adejo A.M.. Reparation to Africa: An Argument For Equity and Alternative Financing Strategy in a Competitve world. URL: http://www.faculty.umb.edu/david.merwin/Reparations_W6.pdf (accessed: 13.02.2017).

2 Ibid. 
progress. As observers are moved to indicate, between the degree of destitution of peoples of Africa and the length and nature of exploitation they had to endure is evident. This is captured in General Ibrahim Babangida's assertion that "The legacies of the past weight too heavily on the present and casts a shadow on our (Africa's) future capacity to develop our economies"3.

A typical reference to such colonial distortion to the progress of African societies was the British punitive expedition against the great Benin (Nigeria) Kingdom of 1897. The British soldiers marched on the city as reprisal for the ambush of members of a 'questionable' peace party to the Oba of Benin [Plakensteiner 2016]. The invaders secured this city and looted monuments and palaces of the King (Oba) and many high-ranking chiefs. The king (Oba) was deported and full imperial control began. This was just one among litanies of such cases of settled African societies being disintegrated by force of imperialist arms so as to build what are now the most advanced economies in the world. Consequently, the African continent today, remains marked by the crimes visited on her by imperialists. Up till now her potentialities are restricted by under-development typified by both the debt-trap and the inequitable terms of trade which conspire to hold the continent down. The question then is, for how long would Africa remain an object of charity and a pawn of international diplomacy? ${ }^{4}$

The paper sets to review the cry for reparation for the African continent. Using the 1897 British Punitive Expedition of the Benin Kingdom (Nigeria) as a reference point, the work emphasizes the need for the reversal of the status quo. The work thus proposes that reparations from the western countries to Africa should be on cooperative and partnership basis not on donor to recipient basis. This should be in favour of development through deliberate international efforts in recompensing Africa for all the ills visited on her by the west.

\section{REPARATION: AN OVERVIEW}

Reparation as often confused in its plural form is the payments that a victorious power seeks from the defeated side to compensate for costs or damages incurred during a war ${ }^{5}$. This is an entirely different meaning of reparation in its singular form. The plural form reparations is a product of power relations in which the defeated (not necessarily the aggressor) is compelled by the victor to pay indemnities. The singular form of the word reparation is defined as some form of restitution aimed at compensating, appeasing and helping the victim to readjust and forget about retaliation [Osabu-Kle 2000: 4]. The philosophical and tactical brilliance of reparations lies in its synthesis of moral principles and political economy. If the crimes and deprivations inflicted on African nations and African descendants over centuries have relied on strategies of dehumanization

3 Adejo A.M.. Reparation to Africa: An Argument For Equity and Alternative Financing Strategy in a Competitve world. URL: http://www.faculty.umb.edu/david.merwin/Reparations_W6.pdf (accessed: 13.02.2017).

4 Ade J.F. Ajayi The Philosophy and History of the Crusade for Reparation. Paper presented at the First Pan African Conference on Reparations at Abuja, 1993, P. 2.

5 Charles S. Maier, Reparation in Microsoft, 2009, Encarta. 
in the service of power, profit, and conquest, then the efforts to identify, halt, and redress them must insist on explicit acknowledgment and repudiation of such strategies, alongside comprehensive material efforts to indemnify them [Btondi 2003]. However, Alfred L. Brophy stressed on the importance to present the context of reparations history in defining it [Brophy 2006].

Reparation, therefore is a recompense, restitution or atonement to an aggrieved people by the perpetrator(s) on the basis of their grief; a means of 'putting into good condition again' or 'being so repaired; a righting of wrong; something done or paid as compensation for a wrong ${ }^{6}$. Implied in these definitions is a suggestion of an initial state of disrepair desirous of rehabilitation — 'thus to repair'; 'to make whole again'7. As Ade Ajayi observed, reparation, in international law, is linked with the concept of crime, and equated with "compensation exacted for past injuries"8. Accordingly Mimiko, citing Ian Brownlie, exposed the legal perspective more aptly when he defined reparations as all measures which a plaintiff may expect to be taken by a defendant state which includes: payment of compensation (or restitution), an apology, the punishment of individuals responsible, the taking of steps to prevent reoccurrence of the breach of duty and any other form of satisfaction [Brownlie 1979].

According to Armstrong Adejo 9 , Reparation in International Law can be discussed in two available forms namely; as specific performance or damages, and as appropriately negotiated award for injury caused. These two forms of compensation known to International Law do not foreclose the employment of any other form of compensation. Thus, for the purpose of our position, reparation is conceived in its expanded yet specific sense as compensations demanded by the past and present generations of Africans from western European and North American nations for what the Africans regarded as the misdeed, exploitation, desecration of and atrocities perpetuated against Africa ${ }^{10}$.

History is replete with concrete evidence of reparations demands and payment. According to Daniel Tetteh, Reparation has been paid directly or indirectly in both ancient and modern history. In Biblical history, Moses indirectly compelled Egyptians lending jewels of silver, gold and raiment to women of Israel to provide the Israelites with the reparation due them for centuries of enslavement in Egypt. The Czar of Russia, Alexander I, after ordering the liberation of the 25 million serfs in 1863 compelled the serfowners to pay reparation by conveying to those serfs the houses in which they lived and portions of the land they had cultivated while working as serfs [Osabu-Kle 2000].

In modern times, reparation has been paid to Jews. The German government and private corporations have paid $\$ 65.2$ billion to survivors of the death camps and forced

${ }^{6}$ Abimbola Awofeso, Abiola M.K.O. To make Whole Again. Lagos: Update Communications; 1990, p. 76.

7 Ibid.

8 Ade Ajayi The Slave Trade, colonialism and Neo-Colonialism in Historical Perspective cited in A.M. Adejo. Reparation to Africa: An Argument For Equity and Alternative Financing Strategy in a Competitve world. URL: http://www.faculty.umb.edu/david.merwin/Reparations_W6.pdf (accessed: 13.02.2017).

9 Ibid.

10 Ibid. P. 19. 
laborers during the Holocaust. The Jews believed that they own the responsibility not to forget, or let the world forget such dehumanizing treatment, so as to ensure that such a crime does not happen again to themselves or others. Germany has also paid reparations to the state of Israel, Korean women, and Japanese Americans for wrongs committed against them. Japan also paid compensation for the "comfort women" it forcibly obtained from Korea during that war. Recently reparation has been imposed on Iraq by the United Nations for its wrongful invasion of Kuwait [Osabu-Kle 2000].

The movement for reparations in Third world nations has also grown in recent years, although not quite as quickly or as broadly as it has in the United States. A major turning point in the development of support for reparations by African nations was the 1993 Abuja Proclamation sponsored by the Organization of African Unity's Reparations Commission [Btondi 2003: 15]. Many activists in Africa identify debt cancellation as an essential first step in reparations. The U.S. human rights organization on Africa Action, has condemned the "illegitimate, immoral and crippling foreign debt that African countries owe to the wealthy white countries and the international institutions that represent their economic interests." Every year, forty-eight countries in sub-Saharan Africa pay $\$ 13.5$ billion to "rich foreign creditors for past loans of questionable legitimacy [Btondi 2003: 16].

Some cases and countries where compensation was received in Africa include; Compensation from British Colonialists on the abuses meted on the Mau Mau Freedom Fighters in Kenya. "The British government sincerely regrets that these abuses took place and that they marred Kenya's progress towards independence" 11 . Britain on this note announced a $£ 19.9$ million (\$30 million) settlement for human rights violations during its colonial rule in the East African nation ${ }^{12}$. Germany also paid for colonial errors in Namibia. In July 2015, the German government and parliament officially called the events a "genocide" and "part of a race war"13. Germany said it is prepared to support a long-term reconciliation programme to address the injustices of German colonial rule in Namibia about 100 years ago ${ }^{14}$. Heidemarie Wiecczorek-Zeul, Germany's Minister of Economic Cooperation and Development, announced that Germany is willing to bankroll an "initiative for reconciliation" to the tune of $\mathrm{N} \$ 160$ million over a period of 10 years ${ }^{15}$.

The Russian President, Dmitry Medvedev, “on June 27, 2009 in Luanda during a visit to Angola stated emphatically thus; "Countries which previously had colonies

${ }^{11}$ UK to compensate more than 5,000 Kenyans over colonial-era torture. URL: http://www.edition.cnn.com/2013/06/06/world/africa/uk-colonial-compensation/ Retrieved, 13 July 2015 (accessed: 13.02.2017).

12 Ibid.

13 German Official Says Namibia Herero Killings Were 'Genocide' And Part Of 'Race War. International Business Times. Retrieved 13 July 2015.

${ }^{14}$ Deutsche Kolonialverbrechen: Bundesregierung nennt Herero-Massaker erstmals "Völkermord" Spiegel Online. 13 July 2015. URL: http://www.spiegel.de/politik/deutschland/namibia-massakerbundesregierung-spricht-von-voelkermord-a-1043117.html (accessed: 12.06.2015). (In German).

${ }^{15}$ Lord Aikins Adusei. US and EuRope Must Pay Reparations to Victims of Slavery and Colonialism. Modern Ghana. URL: http://www.modernghana.com/news/202335/1/us-and-europe-must-payreparations-to-victims-of-s.html (accessed: 13.03.2016). 
in Africa should think to repay their debts to the African continent". The act which deprived the continent of her energetic men and women a vital resource in her development process and sunk the continent into intellectual and developmental wilderness ${ }^{16}$.

\section{THE BENIN OF SOUTHERN NIGERIAN}

The Benins are the Edo (Benin) speaking people of Edo State of Southern Nigeria. It is located in the Guinea rainforest belt of Nigeria in the West Africa sub-region [Ikhidero 2014]. Though Benin City itself falls mainly under Oredo Local Government Area of Edo State, the edo (Benin) speaking people are scattered across several more, like Ovia North-East, Ovia-South West, Egor, Ikpoba Okha, Uhunwmode and Orhionmwon Local Government of Edo State, with Benin City being the State as well as the traditional headquarters where the Palace of the Oba of Benin is situated. The Benin has occupied their present land for thousands of years. Records had shown also that during the era of warrior obas like Ozolua, Esigie and Ewuare, the Benin people built a formidable empire that extended to Lagos, Badagry, Ijebu, Ondo, Owo, Kukuruku, Ikare and as far as Dahomey, Sierra-Leone, Guinea and Ghana; the present $G a$ ethnic group of Ghana migrated from Benin at about 1250 AD. The Benin Kingdom as we have it today has survived the vicissitudes of time and tribulation; its traditional institutions have remained intact and held together by an infallible authority of a monarchy founded more than 800 years ago [Ikhidero 2014].

\section{THE 1897 BRITISH EXPEDITION OF THE BENIN KINGDOM}

The Benin Expedition of 1897 was a punitive expedition by a United Kingdom force of 1,200 under Admiral Sir Harry Rawson in response to the defeat of a previous British-led invasion force under Acting Consul General James Philips (which had left all but two men dead). Rawson's troops captured, burned, and looted Benin City, bringing to an end the West African Kingdom of Benin. As a result, much of the country's art, including the Benin Bronzes, were looted and / or relocated to Britain. By 1895 the British Protectorate government had established its authority, frequently by use of force, over all the major trading centers except the ancient kingdom of Benin which insisted on retaining sovereignty and trading independence. The King had been forced to sign a treaty in 1892. This established the free trade opportunity for the British but limited the sovereignty of the Oba, who was regarded as god by his people.

The British wanted full control of Benin and planned a cunning way of making the use of force inevitable. Benin was besieged in 1897: a reprisal attack after a British mission led by Consul Philip was ambushed consequent upon his refusal to postpone his visit to Benin.

The British soldiers reinforced and conquered Benin forces. The palace of the king was set ablaze, sacred cultural objects were looted from the Oba's chamber and the Oba (Oba Ovoranmwen) was deposed to Calabar. Since this sad event, Benin's cultural arte-

${ }^{16}$ Lord Aikins Adusei. US and EuRope Must Pay Reparations to Victims of Slavery and Colonialism. Modern Ghana. URL: http://www.modernghana.com/news/202335/1/us-and-europe-must-payreparations-to-victims-of-s.html (accessed: 13.03.2016). 
facts are found largely in foreign museums in Britain, Austria, Germany, France and the $\mathrm{US}^{17}$. Obvious facts emerged which have made it clear that the war against the Benin by Britain was premeditated and deliberately provoked by the British. According to Onions Edionwe, in his book Witness to Survival [Edionwe 2010: 14], the British has planned to take control of "Benin Country". Evidence of history reveals that after the abolition of the trade in human chattel (Trans-Atlantic slave trade) in the 1880s, the European merchants turned their attention to commodities like spice, groundnut, palm produce and rubber in the west coast of Africa. European merchants from different European countries found themselves locked in cut-throat rivalry to gain possession of different parts of Africa. In order to check the confusion, the European countries themselves convened what came to be known as the Berlin Conference in 1884, where they agreed that any European country that established sphere of influence anywhere in Africa should claim the area. Thus the real scramble for Africa started.

Hence, in 1897 the British deposed the Oba (King) of Benin and burnt down his palace but not before looting his collection of bronze and ivory that was held in the palace. Today most of that collection is on exhibit at the British Museum in London [Okediji 1998]. Many other objects which have both cultural and spiritual significance and even the remains of our African ancestors are held in western museums in Europe and America $^{18}$.

\section{DEMAND FOR REPARATION BY THE BENINS}

Efforts have been made by the Benins in particular and Nigeria in general to demand restitutions for the looted artifacts and damages done to the Benin people as a result of the British expedition. In a paper presented in 1997 in Lagos during the Centenary Commemoration of the British invasion of the Benin Kingdom, Oba (King) Erediauwa expressly demanded a return of the stolen Benin artifacts by the British Government or pay reparation on them [Edionwe 2010: 27]. The Oba commended the effort of the Federal Government of Nigeria through the National Commission for Museum and Monuments to purchase some of the Stolen Benin Bronze works which enabled few to be brought to the Nigerian Museum. Oba Erediauwa also recalls the fruitless effort that the Federal Government made in 1977 to bring to Nigeria the popular Benin Queen Idia Face mask that was to be known as the FESTAC symbol [Edionwe 2010: 28].

Chief Nosakhare Isekhure; The Isekhure (Chief Priest) of Benin Kingdom, in support of the move of Oba Erediauwa emphasize the importance of those artifact to the Benins and the need for the British to either return them or pay restitutions for these artifact (Onions A. Edionwe p 49). Harrison Okao; the Ohen'Osa, (Priest) of Holy Aruosa Cathedra of Benin Kingdom, added that the looted artifacts are priceless to the $\backslash$ Benin people. Hence, the Benins are not only demanding a return of these items, reparation

17 Layiwola P. Introduction at the Opening of the Colloquium and Exhibition" Benin1897. Com: Art and the Restitution Question. Lagos; 2010.

${ }_{18}$ Gabriel D. Stealing History: The Great Debate on the Repatriation of African Culture Property. 16 October, 2006. URL: http://deborahgabriel.com/wp-content/uploads/2010/05/Stealing-history-thegreat-debate-on-the-repatriation-of-African-cultural-property.pdf (accessed: 16.04.2017). 
has to be paid for them in cash or kind as a form of appeasement for the callous and reckless actions of the British Royal Army in 1897. He appealed to the United Nation through UNICEF and any of its archeological body to come to the rescue of the Benins in this regard by providing an assessment of the needed reparation. He advocated also for an alternative move which should be an adjucation at the world court, at which public hearing, will reveal the unkind act of Britain towards the Benins [Edionwe 2010: 58].

\section{OPPOSING ARGUMENTS ON REPARATION}

Before further assessment on the argument opposing reparation, it's imperative to sum up Key ethical questions on reparation, which $\operatorname{are}^{19}$ :

- How can people repair the damage brought about or suffered by their ancestors?

- Can money, whether in the form of foreign aid to those countries most affected by the slave trade or of payments to slaves' descendants of slaves, begin to heal the wounds of the past? (If not, what can?)

- How are reparations linked to the ongoing social, economic, health, and political crises that continue to wrack the ex-colonial nations that supported the slave trade for so many centuries?

- Finally, what moral obligations do people living today have towards the descendants of slaves and towards members of societies most heavily impacted by the slave trade?

Against this background, different scholars have given their views as opposed to the idea of reparations. Some argue that it is disrespectful and dishonorable to reduce the horrors of the slave trade to financial compensation. Others feel that accepting compensation for past wrongs will mean that the developed world will feel that it has done its duty by Africa.

Michelson Melissa R. [Michelson 2002], posit that, to those who argue that compensation cannot be made to slaves because there are no living former slaves, reparations supporters counter that although slavery officially ended in 1865, there is substantial evidence that the practice continued illegally well into the 20th century and that Blacks should be compensated for injuries. Opponents such as David Horowitz (2001) ${ }^{20}$ argue that, unlike the Jews who suffered through the Holocaust or the Japanese-Americans awarded remunerations for WWII internment by the U.S. government, neither the victims nor the perpetrators of slavery are alive today, and it is unfair to hold the descendants of slave-owners responsible for the actions of their ancestors.

He however, in his famous "Ten Reasons Why Reparations for Slavery are a Bad Idea and Racist, Too", argued that [Horowitz 2001]:

- There Is No Single Group Clearly Responsible for The Crime of Slavery,

- There Is No One Group That Benefitted Exclusively from Its Fruits,

- The Historical Precedents Used to Justify the Reparations Claim Do Not Apply, And The Claim Itself Is Based On Race Not Injury.

${ }_{19}$ Special Report: Reparations for Slavery Debate//Carnegie Council. August 19, 2001. URL: https://www.carnegiecouncil.org/publications/picks/175 (accessed: 16.04.2017).

${ }^{20}$ Horowitz D. (2002). Uncivil Wars: The Controversy Over Reparations For Slavery 12-16. 
While the morale argument of one not liable to pay for what he never did, as many reparations sceptics do, that implies that one should be liable only for the harms one causes, that there is no general societal culpability. The question it raises is, where is the fairness in asking people whose ancestors were not even in the country that purportedly committed the crime during the period of slavery to pay reparations for crimes occurring in that time? [Brophy 2004]. Moreover, other entities besides the government have culpability for slavery, such as African nations themselves. Blacks have little to gain and much to lose from making "Reparations Now" the next civil rights rallying cry [Loury 2001].

However, Adjoa Aiyetoro ${ }^{21}$, has said: "We're not raising claims that you should pay us because you did something to us 150 years ago. We are saying that we are injured today by the vestiges of slavery, which took away income and property that was rightfully ours". Yet proponent against reparation frequently maintain that the current inequality in wealth is due to black culture, not the legacy of slavery. While on the other hand, Journalist Walter Williams, like many other proponents not in favour of reparation, places blames.

According to the argument of Journalist Walter Williams"2, "Had there not been slavery, and today's blacks were born in Africa instead of the United States, we'd be living in the same poverty that today's Africans live in and under the same brutal regimes. This however point to the fact that African leaders have a role to also play in bettering the lives of it citizen and not always seeking for help and reparation which it however, intend to place on colonialism. In supporting the same view is David Horowitz, who also pointed out that the average annual income of residents in Benin is less than one thousand dollars, that has little relevance to how people are treated in the United States. This therefore places much of the blame on the lack of development of Africa on its leaders.

Dr Stephen Small of the University of Leicester on the reparations movement, the descendants of Africans and of Europeans view the legacy of the slave trade from different vantage points ${ }^{23}$. However, it's only by tackling the unfairness of these systems can we begin together to create a more morally acceptable economic and political system within which the world's entire population can prosper.

\section{PROPOSED STRATEGY}

The reparations from the western countries to Africa should be on cooperative and partnership basis not on donor to recipient basis. It should be based on Cooperation and Partnership theory. The reparation to the Benin kingdom for the massacre and stolen artifacts, if paid will also go a long way in the developmental process of the Kingdom

${ }^{21}$ Adjoa A. Aiyetoro The National Coalition of Blacks for Reparations in America (N'COBRA): Its Creation and Contribution to the Reparations Movement. In: Should America Pay? N 53, 209, 225.

22 Williams W. Did blacks benefit from slavery? Orange County Register (OCR). October 24, 2012. URL: http://www.ocregister.com/2012/10/24/walter-williams-did-blacks-benefit-from-slavery (accessed: 16.04.2017).

${ }^{23}$ Reparations. Discovering Bristol. URL: http://www.discoveringbristol.org.uk/slavery/after-slavery/ wider-world/african-diaspora/reparations (accessed: 16.04.2017). 
and will eventually create jobs for many. Speaking in a cultural exhibition in Sweden, Orobosa Omo-Ojo urged the British government to pay reparation for the economic benefits accruing to the artifacts for all those years. He stressed that the ugly and unwarranted episode of 1897, when the British government planned and invaded the Benin Empire marked the turning point in the history of Benin and the black civilization in general.

Akeem Lasisi added that the looted Benin artifacts and other damages worth more than N313bn, which can be invested in building infrastructures that will employ more than 10,000 people, each of which can take care of about 15 dependants; at the end we will have a total of 150,000 people that will be affected positively. With cooperation, collaboration and partnership, the partnership can then create mutual benefits and particularly, for the better development of the people and the nation. On the other hand, $\mathrm{K}$. Hopkins asserted in his conclusion that the granting of reparations to blacks is not only morally and legally justified but also only a starting point in any genuine attempt to right the wrongs of slavery [Hopkins 2001].

The paper explored the Africa's reparation call. It emphasized among other things that the continued underdevelopment and marginalization of the African continent today, is not unconnected with the trilogy of slavery, imperialism and colonialism. From the perspective of the British expedition of the Great Benin Kingdom in 1897, the paper highlighted how the African continent had been strengthen the economies of their colonial overlords.

It is against this background for a safer world that we join in the call for reparation as a moral justice for Africa. This is anchored on the premise that reparation is not only recognized in international law, it has been paid to some countries of the world.

\section{REFERENCES}

Brophy, A. L. (2006). Reconsidering Reparations. Indiana Law Journal, 81 (3), 812-849.

Brophy, A. L. (2004). The Cultural War over Reparations for Slavery. DePaul Law Review. 53 (3), $1181-1213$.

Brownlie, I. (1979). Principles of International Law. London: Oxford University Press.

Btondi, M. (2003). The Rise of Reparation Movement. Radical History Review Journal, 87, 5-18. DOI: $10.1215 / 01636545-2003-87-5$.

Edionwe, O. A. (2010). Witness to Survival; Kingdom vs. Kingdom. Benin: Butterworth Productions Limited; 2010.

Hopkins, K. (2001). Forgive U.S. Our Debts? Righting the Wrongs of Slavery. Georgetown Law Journal, 89 (8), 2531-2556.

Horowitz, D. (2001). Ten Reasons Why Reparations for Slavery is a Bad Idea for Blacks — and Racist Too. Journal of Black Studies and Research, 31 (2), 48. DOI: 10.1080/00064246.2001.11431145.

Ikhidero, S. I. (2014). The Matrimonial Oath of Fidelity among the Benin of Southern Nigeria: Its Ethical Implications for Postcolonial Nigeria. Germany: Lap Lambert Academic Publishing.

Loury, G. C. (2001). Little to Gain, Much to Lose. Black Issues in Higher Education, 18 (19), 42.

Michelson, M. R. (2002). The Black Reparation Movement: Public Opinion and Congressional Policy Making. The Journal of Black Studies, 32 (5), 574-587.

Okediji, M. (1998). On Reparations Exodus and Embodiment. African Arts, 31 (2), 8-10. 
Osabu-Kle, D. T. (2000). The African Reparation Cry: Rationale, Estimate, Prospects, and Strategies. Journal of Black Studies, 30 (3), 1-15.

Plakensteiner, B. (2016). Benin: Kings and Rituals-Court Arts from Nigeria. Snoeck Publishers. URL: http://artwriteups.blogspot.com.ng/2010/08/benin-1897com-art-and-restitution_02.html (accessed: 20.02.2016).

For citations: Idahosa, S.O., Onimhawo, J.A., \& Ikhidero, S.I. (2017). Reparation a morale justice for Africa: the Benin (Nigeria) in perspective. Vestnik RUDN. International Relations, 17 (2), $301-311$.

\begin{abstract}
About the authors: Idahosa Stephen Osaherumwen - graduate student of the Department of Theory and History of International Relations, Peoples' Friendship University of Russia (RUDN University) (e-mail: idahosa8@gmail.com).

Onimhawo John Afeagbokhai - Professor in the Department of Religious Management and Cultural Studies, Ambrose Alli University, Nigeria, Editor of Epkoma Journal of Religious Studies (e-mail: onims_j54@yahoo.com).
\end{abstract}

Ikhidero Solomon Ijeweimen — graduate student of Ambrose Alli University, Nigeria (e-mail: solomonikhidero@yahoo.com)

DOI: $10.22363 / 2313-0660-2017-17-2-301-311$

\title{
ВОЗМЕЩЕНИЕ МОРАЛЬНОГО УЩЕРБА АФРИКЕ: НА ПРИМЕРЕ БЕНИНСКОГО ЦАРСТВА (НИГЕРИЯ)
}

\author{
С.О. Идахоса \\ Российский университет дружбы народов, Москва, Россия
}

Д.А. Онимхаво, С.И. Ихидеро

Университет Эмброуза Алли, Экпома, Нигерия

В данной статье предлагается анализ призыва Африки к возмещению морального ущерба. В ней, среди прочего, подчеркивается, что продолжающееся отставание в развитии и маргинализация Африканского континента на сегодняшний день связаны, в том числе с наследием рабства, империализма и колониализма. На примере британской экспедиции в Бенинское царство в 1897 г. авторы данного исследования делают вывод, что Африканский континент подвергся жестокому обращению ради укрепления экономик метрополий. В ней также проводится анализ репараций, которые не только признаются международным правом, но и выплачиваются ряду пострадавших стран, которые не испытывали столь длительного и бесчеловечного обращения, как Африка на протяжении более 500 лет, долгих лет ущерба и разрушения, вызванных рабством, империализмом и колониализмом.

Также в статье рассмотрены точки зрения, которые отрицают идею о возмещении ущерба. Авторы приходят к выводу, что репарации западных стран Африканскому континенту должны осуществляться на основе сотрудничества и партнерства. Это должно идти на пользу развитию африканских стран и реализовываться путем продуманных международных усилий по компенсации.

Ключевые слова: репарации, империализм, колониализм, справедливость, западные державы, Бенинское царство

Дата поступления статьи: 14.03.2017 
Для цитирования: Idahosa S.O., Onimhawo J.A., Ikhidero S.I. Reparation a morale justice for Africa: the Benin (Nigeria) in perspective // Вестник Российского университета дружбы народов. Серия: Международные отношения. 2017. Т. 17. № 2. С. 301-311.

Сведения об авторах: Идахоса Стефен Осахерумвен - магистрант кафедры теории и истории международных отношений Российского университета дружбы народов (e-mail: idahosa8@gmail.com).

Онимхаво Джон Афеабокай - профессор Департамента религиозных и культурных исследований Университета Эмброуза Алли, Экпома, Нигерия, редактор Epkoma Journal of Religious Studies (e-mail:onims_j54@yahoo.com).

Ихидеро Соломон Айджевайнен - магистрант Университета Эмброуза Алли, Экпома, Нигерия (e-mail: solomonikhidero@yahoo.com)

(C) Idahosa S.O., Onimhawo J.A., Ikhidero S.I., 2017 